
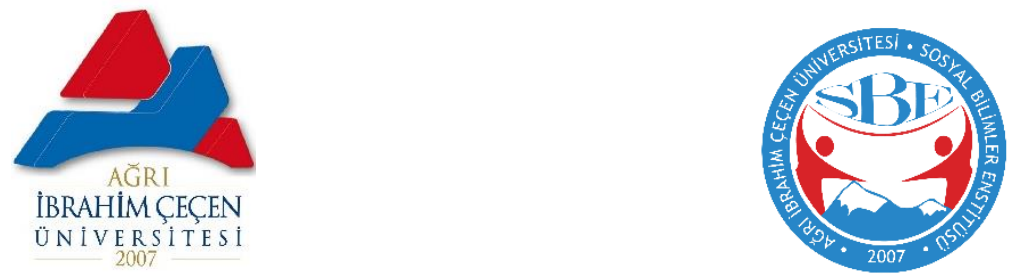

OKUMA STRATEjILERININ (YÖNTEM VE TEKNIKLERININ) TÜRKÇE DERS KITAPLARINDAKI METINLERLE UYUMU

Reading Strategies (Methods and Techniques) Relevance with Texts In Turkish Course Books

Dr. Öğr. Üyesi Metin ERKAL

Ağrı Ibrahim Çeçen Üniversitesi, Eğitim Fakültesi, Türkçe ve Sosyal Bilimler Eğitimi Bölümü/Türkçe Eğitimi Anabilim Dahı merkal@agri.edu.tr

iD https://orcid.org/0000-0002-7107-5558

\title{
Damla ÇAĞRITEKIN
}

Ağrı Ibrahim Çeçen Üniversitesi, Sosyal Bilimler Enstitüsü, Türkçe Eğitimi Anabilim Dalı Yüksek Lisans Öğrencisi damlacagritekin@hotmail.com

iD https://orcid.org/0000-0003-4264-5782

Ağrı Ibrahim Çeçen Üniversitesi Sosyal Bilimler Enstitüsü DergisiJournal of Ağrı Ibrahim Çeçen University Social Sciences Institute-

AiCUSBED 6/2 Ekim /October2020 / Ağrı

ISSN: 2149-3006

\begin{tabular}{|l|l|}
\hline Makale Türü-Article Types : & Araştırma Makalesi \\
\hline Geliş Tarihi-Received Date $:$ & 27.07 .2020 \\
\hline Kabul Tarihi-Accepted Date $:$ & 28.10 .2020 \\
\hline Sayfa-Pages $: 433-450$ & \\
\hline
\end{tabular}

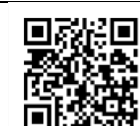

http://dergipark.gov.tr/aicusbed

This article was checked by

$\checkmark$ iThenticate 



\begin{tabular}{|l|} 
AĞRI i BRAHIM ÇEÇEN ÜNiVERSiTESi \\
SOSYAL BiLiMLER ENSTiTüSü DERGiSi \\
Journal of Ağr ibrahim Çeçen University Social Sciences Institute \\
AiCUSBED 6/1, 2020, 433-450
\end{tabular}

\title{
OKUMA STRATEJILERININ (YÖNTEM VE TEKNIKLERININ) TÜRKÇE DERS KITAPLARINDAKI METINLERLE UYUMU
}

\author{
READING STRATEGIES (METHODS AND TECHNIQUES) RELEVANCE WITH \\ TEXTS IN TURKISH COURSE BOOKS \\ Dr. Öğt. Üyesi Metin ERKAL \\ Damla ÇAĞRITEKIIN
}

\section{$\ddot{O} z$}

Diğer ülkelerin eğitim sistemlerinde olduğu gibi ülkemizde de Türkçe eğitiminin genel amacı dile ait kelime ve dil bilgisi kazanımları ayırt edilmeksizin dört temel dil becerisinin geliştirilmesidir. Bu hedef için okullarımızda kullanılan ders kitapları öğretmenlerin ve öğrencilerin en büyük yardımcısıdır. Müfredatta her kademe için dil becerilerinin kazanımına yardımcı olarak stratejiler belirlenmiştir. Ancak ders kitaplarında yer yer müfredatta olmayan yöntemler de dikkati çekmektedir. Bu çalışmanın amacı Türkçe Dersi Öğretim Programında gösterilen okuma stratejilerinin ders kitaplarındaki okuma metinleriyle uyumunun incelenmesidir. Çalışma tarama modeli uygulanarak tamamlanmıştır. Veri toplama aracı olarak ortaokul Türkçe ders kitapları kullanılmıştır. Çalışma sonunda Türkçe ders kitaplarındaki bazı metinlerin müfredatta yer almayan okuma yöntem ve teknikleriyle ilişkilendirildiği tespit edilmiştir. Tartışarak okuma, göz atarak okuma ve özetleyerek okuma yöntemlerinin müfredatta yer almasına rağmen ders kitaplarında bulunmadığg tespit edilmiştir.

Anahtar Kelimeler: Türkçe eğitimi, müfredat, okuma yöntemleri, metinler

\begin{abstract}
The aim of Turkish education in our country is to develop four basic language skills regardless of grammer and vocable gains as in the other countries education system. Textbooks used in schools for this aim are the greatest helpers of teachers and pupils. In the curriculum, have been determined to help the achievement of language skills at all level. However, strategies that are not included in the curriculum in the textbooks attract attention. The aim of this article is to examine the compability of the reading strategies shown in the Turkish Language Teaching Program with the reading texts in the textbooks. The search, completed by applying a survey model. Secondary school Turkish textbooks were used to data collect. At the end of the study, it was determined that some texts in Turkish textbooks were associated with reading methods and techniques not included in the curriculum.
\end{abstract}

Keywords: Turkish education, curriculum, reading strategies, texts

http://dergipark.gov.tr/aicusbed 6/2 Ekim / October 2020 


\section{Giriş}

Türkçe eğitimi; öğrencilerin dilini ve kültürünü tanımaları, geliştirmeleri, etkili iletişim becerilerini daha verimli kullanabilmeleri, problem çözme becerilerine sahip olabilmeleri açısından büyük bir öneme sahiptir. Temelinde ana dili eğitimi yatan Türkçe öğretiminin hedefi, Türkçe dersinin dört temel dil becerisi olan; dinleme, konuşma, okuma ve yazma alanlarını öğrenciye kazandırmaktır.

$\mathrm{Bu}$ dört temel dil becerisinden biri olan okuma, Karatay'a göre (2014:1) yazılı olan bir metni bilinen yazı karakterlerini sesli veya sessiz çözmenin ötesinde, metnin içindeki duygu, düşünce ve iletileri anlamaktır. Anlamanın bir parçası olduğu için eğitimde her kademede ve her derste en önemli dil aracıdır. Çünkü öğrenciler, Türkçe, Matematik, Fen Bilgisi, Sosyal Bilgiler vb. tüm derslerde okuduklarını anlayamazlarsa üstün bir başarı gösteremezler. Albayrak ve Erkal'ın (2003: 174-180) çalışmasında, konuşma ve yazma ağırlıklı olarak işlenen matematik derslerinin öğrencilerin Türkçe derslerindeki yeterlikleri orantısında hedefe ulaşabileceği, bu bağlamda her iki dersin birlikteliğinin sağlanması gerektiği vurgulanmaktadır. Okuma, geliştirilemeyen ve gelişemeyen bir beceri değildir. Eğitim ve öğretimdeki yeni yöntem ve tekniklerle dinleme, konuşma ve yazma becerileri geliştirilebildiği gibi okuma becerileri de büyük oranda gelişebilmektedir.

Eğitim-öğretim hayatına başladığ faaliyetlerine hızla adım atan ve önce sesleri çıkaran sonunda cümleyi kurmayı başaran öğrencinin bu cümleyi zihinsel süreçte anlamlandırması beklenir. İnsan okuduğunu anlayamadığı sürece yalnızca gördüğü kelimeleri seslendirmekten öteye gidemez. Ancak bazen öğrencilerin okuduğunu anlayamama ya da okuduğunu eksik anlama gibi problemlerle karşılaştığı görülür. Hall ve Browman'a göre (1993: 99, akt. Temizkan, 2009: 44) okuduğunu anlayamamanın temelinde beş neden bulunur.

"1. Kelimeyi anlayamama,

2. Cümleyi anlayamama,

3. Cümlelerin birbirleriyle ilişkilerini anlayamama,

4. Metindeki bilgi ve düşüncelerin birbirleriyle ilişkilerini, metin içindeki düzenlenişlerini anlayamama,

5. Motivasyon ve ilgi eksikliği."

Göğüş'e göre (1978: 75) okuduğu metni eksik veya yanlış anlamanın sebepleri şunlar olarak sıralanmıştır:

"a. Metinde anlamı bilinmeyen kelimelerin çokluğu,

b. Sanatların çok kullanılması, 
c. Konunun veya kavramların okuyucuya yabancı olması,

ç. Bilgi ve beceri eksikliği,

d. İlgi ve ihtiyaç dışı okumalar,

e. Motivasyonun sağlanamaması,

f. Okuma ortamının uygun olmaması vb."

Örneğin öğrenciler, biyoloji ve kimya gibi içinde çokça Latince kelime bulunduran derslerin metinlerini okumakta ve anlamakta güçlük çekebilirler. Çünkü bu tür metinlerde kelimeler, terim anlamlarıyla kullanıldığı gibi bu kelimelerin Türkçeye yabancı oluşları da anlamlandıramamanın sebeplerinden birini oluşturur. Öğrencilerin coğrafya dersinde okuma metinlerini şema, harita, grafik vb. iki boyutlu görsel materyaller ile organize edememeleri hâlinde okuduğunu anlaması beklenemez. Öğrencilerin hazır bulunuşluk seviyelerinin yeterli düzeyde olmaması ve metnin dikkatli okunmaması, okuduğunu anlamalarını güçleştirir.

Okuduğunu anlamanın temelinde kelimelerin anlamlarını bilmek, daha sonra da cümleye anlam vermek yatmaktadır. Ancak cümleyi anlamlandırmak okuduğunu anlamanın son safhası değildir. Günümüzde cümleyi anlamlandırdıktan sonra metni yorumlamak ve değerlendirmek de tam anlamanın bir parçasıdır. (Arıcı, 2009: 62)

Ancak eksik ve yanlış anlamalar, okumanın anlamlandırılması sürecinde okuma yöntem ve teknikleriyle birlikte en aza indirilebilir. Okuma, genel anlamda sesli okuma ve sessiz okuma gibi boyutlarıla bilinse de okuma alanında değişik yöntem ve tekniklerin kullanılmasıyla okumanın ve okuduğunu anlamanın etkililiği artabilmektedir.

Yöntem ve teknikler, okumada anlamlandırmayı kuvvetlendirir ve kalıcı öğrenmeyi sağlar. Okuma eğitiminde kullanılabilecek bu yöntem ve teknikler farklı öğrenme stillerindeki öğrenciler açısından anlamayı kolaylaştırır. Metnin amacına, türüne ve özelliğine uygun olarak seçilen yöntemler okuduğunu anlamada kolaylık sağlar.

Okuma becerisi ve alışkanlığının temel amacı; bilgi edinmek, eğlenmek, haberleşmek, kendini geliştirmek gibi amaçlarla yazılı veya çizili metinleri anlamlandırabilmek ve edinilen anlamı var olan ön bilgi ve tecrübelerle yapılandırabilmektir. Okuma eğitimi, bu amaca bağlı olarak öğrencilere okuma becerisinin temel yeterliklerini kazandırır ve bunların yaşam boyu sürdürülmesi için gereken bilinç ve farkındalığı aşılar. Okuma eğitiminde kullanılacak yöntem ve tekniklerde de dil becerileri ile bütünlük

http://dergipark.gov.tr/aicusbed 6/2 Ekim / October 2020 
içerisinde hayat boyu sürdürülebilecek bir okuma ve anlamlandırma hedeflenmelidir. (Maden, 2018: 235)

Metnin içeriğini çözümlemeye dönük her çaba, metni anlamaya yönelik bir arayışın ifadesidir. Metni anlamaya, tanımaya, özetlemeye çalışmak, anlamadan sonraki aşamadır. Anlamadığımız bir metni anlatmamız mümkün değildir. Bir metni anlamak için, teknik bilgiye ihtiyaç olduğu kadar, alan bilgisine de ihtiyaç vardır. Okurun hazır bulunuşluk düzeyi metni anlamada önemli bir anahtardır. (Gündüz ve Şimşek, 2013: 44)

2017-2018 eğitim-öğretim y1lında uygulamaya konulan 5. Sinıf Türkçe Dersi Öğretim Programı'na göre hazırlanan MEB yayınevi tarafından yayımlanan Türkçe Ders Kitabının öğretmen görüşlerine göre değerlendirilmesini araştıran Arslan ve Engin (2019) araştırmasında, öğretmenlerin Türkçe Ders Kitabında yer alan metin ve kazanımların öğretim programıla uyumlu olduğunu belirttiklerini; kitabı kullanırken zaman sıkıntısı, materyal eksikliği ve kılavuz kitabının olmaması şeklindeki olumsuzluklardan bahsedildiğini aktarmışlardır.

2018 yılında yenilenen ortaokul Türkçe ders kitaplarının ders işleme süreci ve etkinlikleri, metinlerin öğretime uygunluğu açılarından olumlu ve olumsuz yönlerinin belirlenmesi amaciyla Mutlu, Süğümlü ve Çinpolat'ın (2019) yaptığı çalışmada, Türkçe ders kitaplarının derse hazırlık açısından bütünlük içinde olduğundan yararlı olduğunu ancak kitaplarının ders hazırlığı sağlayamaması yönünden olumsuzluk oluşturduğunu belirtmişlerdir. Türkçe öğretmenleri, kitapların derse hazırlık açısından yeterli oldukları üzerinde daha fazla görüş belirtmişlerdir.

Ders kitapları, öğrencilerin bilgi alabildikleri en genel öğretim araçlarıdır. Şahin'e göre (1988) ders kitapları, öğrencilere rehberlik edebilecek, onların her zaman ulaşabilecekleri temel kaynak; Gülersoy'a göre (2013) ise ders kitabı, belli bir dersin öğretimi için ve belli bir düzeydeki öğrencilere yönelik olarak yazılan; içeriği öğretim programına uygun olan, incelemesi yapılmış ve onaylanmış temel kaynaktır. Çalışkan (2016) araştırmasında Türkçe öğretimi temelinin ders kitabına ve bu ders kitabında seçilmiş metinlerin niteliğine bağlı olduğunu ve her ne kadar yalnızca ders kitabına bağlı kalınarak öğrenme-öğretme sürecini düzenlemek yanlışsa da Türkiye'nin koşulları düşünüldüğünde tek kaynaklı bir öğrenme-öğretme sürecinde ders kitabının öneminin çok büyük olduğunu belirtmiştir. Ders kitaplarıyla müfredat programının uyumlu olması ise hem öğrencinin gelişim özellikleri hem de öğretmenin ders anlatımını farklılaştırması açısından önemlidir. 
MEB Türkçe Öğretim Programı'na bakıldığında, 5. sınıf okuma alanında aşağıdaki kazanımda bulunan okuma yöntem ve teknikleriyle ortaokul 5. sınıf öğrencilerinin bu okuma yöntem ve tekniklerinin uygulanmasıyla okuduğunu anlamalarında artış gözlenmesi beklenmektedir.

"T.5.3.4. Okuma stratejilerini kullanır. Sesli, sessiz, tahmin ederek, grup hâlinde, soru sorarak, söz korosu, ezberleyerek ve hızlı okuma gibi yöntem ve teknikleri kullanmaları sağlanır." (MEB, 2019: 36)

MEB Türkçe Öğretim Programı'na bakıldığında, 6. sınıf okuma alanında aşağıdaki kazanımda bulunan okuma yöntem ve teknikleriyle ortaokul 6. sınıf öğrencilerinin bu okuma yöntem ve tekniklerinin uygulanmasıyla okuduğunu anlamalarında artış gözlenmesi beklenmektedir.

"T.6.3.4. Okuma stratejilerini kullanır. Sesli, sessiz, tahmin ederek, not alarak, soru sorarak, okuma tiyatrosu ve hızlı okuma gibi yöntem ve teknikleri kullanmaları sağlanır." (MEB, 2019: 40)

MEB Türkçe Öğretim Programı'na bakıldığında, 7. sınıf okuma alanında aşağıdaki kazanımda bulunan okuma yöntem ve teknikleriyle ortaokul 7. sınıf öğrencilerinin bu okuma yöntem ve tekniklerinin uygulanmasıyla okuduğunu anlamalarında artış gözlenmesi beklenmektedir.

"T.7.3.4. Okuma stratejilerini kullanır. Göz atarak, özetleyerek, not alarak, işaretleyerek ve tartışarak okuma gibi yöntem ve teknikleri kullanmaları sağlanır.” (MEB, 2019: 44)

MEB Türkçe Öğretim Programı'na bakıldığında, 8. sınıf okuma alanında aşağıdaki kazanımda bulunan okuma yöntem ve teknikleriyle ortaokul 8. sınıf öğrencilerinin bu okuma yöntem ve tekniklerinin uygulanmasıyla okuduğunu anlamalarında artış gözlenmesi beklenmektedir.

"T.8.3.4. Okuma stratejilerini kullanır. Göz atarak, özetleyerek, not alarak, tartışarak ve eleştirerek okuma gibi yöntem ve teknikleri kullanmaları sağlanır.” (MEB, 2019: 48) 
Tablo 1. 2018 MEB Müfredatında Sınıf Kademelerine Göre Okuma Yöntem ve Teknikleri

\begin{tabular}{|l|l|l|l|l|}
\hline \multicolumn{1}{|c|}{ Okuma Yöntem ve Teknikleri } & \multicolumn{4}{c|}{ Sinıflar } \\
\hline & 5 & 6 & 7 & 8 \\
\hline Sesli Okuma & X & X & & \\
\hline Sessiz Okuma & X & X & & \\
\hline Tahmin Ederek Okuma & X & X & & \\
\hline Not Alarak Okuma & & X & X & X \\
\hline Grup Halinde Okuma & X & & & \\
\hline Soru Sorarak Okuma & X & X & & \\
\hline Söz Korosu & X & & & \\
\hline Ezberleyerek Okuma & X & & & \\
\hline Hızlı Okuma & X & X & & \\
\hline Okuma Tiyatrosu & & X & & \\
\hline Göz Atarak Okuma & & & X & X \\
\hline Özetleyerek Okuma & & & X & X \\
\hline İşaretleyerek Okuma & & & X & \\
\hline Tartş̧arak Okuma & & & X & X \\
\hline Eleştirel Okuma & & & & X \\
\hline
\end{tabular}

\section{PROBLEM DURUMU}

Yukarıda verilen okuma yöntem ve teknikleri incelendiğinde, bunların sınıf düzeylerine göre aşamalı bir şekilde yerleştirildiği görülmektedir. 5. ve 6. sinıf öğrencileri henüz yeterli düzeyde okuyucu olmadıkları için anlamlandırma süreçleri daha karmaşık olan eleştirerek okuma, tartışarak okuma, özetleyerek okuma gibi türler 7 . ve 8 . sınıfların kazanımı olarak karşımıza çıkmaktadır. Ancak 5, 6, 7 ve 8. sınıf Türkçe kitapları incelendiğinde MEB müfredatı ile Talim ve Terbiye Kurulu Başkanlığının kabul ettiği Türkçe kitapları arasında bir uyumsuzluk göze çarpmaktadır. $\mathrm{Bu}$ bağlamda bu araştırmanın temel problem cümlesi "Müfredatta yer alan okuma yöntem ve teknikleri Türkçe ders kitaplarındaki metinlerle uyumlu mudur?)" olacaktır. Bu bağlamda aşağıdaki alt problemlere cevap aranacaktır.

\section{Alt Problemler}

1- 5. sınıf Türkçe kitabındaki okuma yöntem ve metinler arasında görülen uyumsuzluklar nelerdir?

http://dergipark.gov.tr/aicusbed 6/2 Ekim/ October 2020 
2- 6. sınıf Türkçe kitabındaki okuma yöntem ve metinler arasında görülen uyumsuzluklar nelerdir?

3- 7. sınıf Türkçe kitabındaki okuma yöntem ve metinler arasında görülen uyumsuzluklar nelerdir?

4- 8. sınıf Türkçe kitabındaki okuma yöntem ve metinler arasında görülen uyumsuzluklar nelerdir?

5- Ortaokul ders kitaplarındaki okuma yöntem ve tekniklerinin müfredata göre dağılımı nasıldır?

\section{Araştırmanin Amacl}

2017 yılına kadar öğretmen kılavuz kitaplarında okuma metinlerinin hangi yöntem ve tekniklerle okunması gerektiği, öğretmenin hangi çalışma yöntemini uygulayacağı verilmekteydi. Kılavuz kitapların kaldırılmasıyla öğrencilerin ders kitaplarında, okuma parçalarının başında öğretmenlere bazen metnin hangi okuma yöntemiyle okunması gerektiği doğrudan belirtilmekte bazen de adı verilmeden hangi okuma yöntemi uygulaması gerektiği sezdirilmektedir. 2019-2020 eğitim-öğretim yılında okutulmakta olan Türkçe ders kitaplarında, müfredatın dışında okuma yöntem ve teknikler kullanıldığı fark edilmiş olup bu araştırmada, bunların ortaya çıkarılması amaçlanmıştır.

\section{Araştırmanin Sinırlılıkları}

1) Bu araştırma, 2019-2020 öğretim yılından itibaren beş yıl süreyle ders kitabı olarak kabul edilen aşağıdaki eserlerle sınırlandırılmıştır:

5. Sınıf Türkçe Ders Kitabı, Anıttepe Yayıncılık.

6. Sınıf Türkçe Ders Kitabı, Ekoyay Yayıncılık.

7. Sınıf Türkçe Ders Kitabı, Özgün Yayıncılık.

8. Sınıf Türkçe Ders Kitabı, MEB Yayınları.

2) $\mathrm{Bu}$ ders kitaplarındaki sadece okuma metinleri ele alınmıştır. Serbest okuma metinleri ve dinleme metinleri incelemeye dâhil değildir.

\section{YÖNTEM}

$\mathrm{Bu}$ araştırmada, genel tarama modeli kullanılmıştır. Genel tarama modelleri, çok sayıda elemanlardan oluşan bir evrende, evren hakkında genel bir yargıya varmak amacıyla evrenin tümü ya da ondan alınacak bir grup örnek ya da örneklem üzerinde yapılan tarama düzenlemeleridir. (Karasar, 2004: 79)

Veri Toplama Araçları

Kullanılmakta olan ortaokul Türkçe ders kitaplarında 8 tema bulunmaktadır. Bu temaların içerisinde 3 okuma metni, 1 dinleme ve 1 serbest okuma metni mevcuttur. Her kademede toplamda 24 okuma metni bulunmaktadır. Bu araştırmada, 5. sınıf okuma metinleri için 24; 6. sınıflar 
için 24; 7. sınıflar için 24 ve 8. sınıflar için 24 toplamda 96 metin incelenmiştir. Bunların kitapta hangi okuma yöntemine yönlendirildiği incelenmiștir.

\section{Veri Analizi}

Çalışmanın veri analizi 2019-2020 öğretim yılında kullanılan 5, 6, 7 ve 8. sınıf ders kitaplarındaki okuma metinleri incelenerek yapılmıştır. Müfredatta yer alan okuma yöntem ve teknikleri ile metinlerde yer alan teknikler karşılaştırılarak tablolar oluşturulmuştur.

\section{BULGULAR}

1. 5. Sınıf Türkçe Kitabındaki Okuma Yöntem ve Metinler Arasında Görülen Uyumsuzluklar

5. sınıf okuma kazanımlarında, yalnızca sesli, sessiz, tahmin ederek, grup halinde, soru sorarak, söz korosu, ezberleyerek ve hızlı okuma yöntemlerine yer verildiği halde ders kitabındaki okuma metinleri incelendiğinde, yönergelerinde diğer okuma yöntemlerinin adı geçmeden uygulanması istenmektedir. Aşağıdaki yönergelerde 5. sınıf ders kitabında yer alan bazı okuma metinlerinin yönlendirmesi yer almaktadır.

- Metni noktalama işaretlerine dikkat ederek sessiz okuyunuz. Metni okurken önemli gördügüüüz yerleri defterinize not ediniz.

“Anadolu Selçukluları Devri'nden Osmanlıların son yıllarına kadar bir esnaf ve sanatkâr örgütü olarak bilinen Ahiliğin her köyde, her kasaba ve şehirde ocaklart, odalart ve tekkeleri vardir. Ahiler, gelen konuklart geleneksel kurallarına göre ağırlar, bunu bir toplum görevi sayarlardı." Kısaltılmıştır. (Önder, 2019: 23)

"Anadolu'da Konukseverlik Gelenekseldir" adlı metinde, öğretmenden öğrencilere sessiz okuma yaptırmaları beklenmektedir. Sessiz okuma 5. sınıf müfredatında yer alan bir okuma yöntemiyken; önemli gördüğünüz yerleri not edin, diyerek aslında öğrencileri not alarak okumaya yönlendirmektedir. Metin içeriği bakımından not alarak okumaya uygun bir metindir. Ancak bu okuma yöntemi 5. sınıf müfredatında okuma kazanımlarında yer almamaktadır. Not alarak okuma yöntemi müfredata göre 6. sınıftan itibaren ders kitaplarında yer alması ve yönlendirilmesi gereken bir okuma yöntemidir.

- Metni sessiz okuma yöntemi ile noktalama işaretlerine dikkat ederek okuyunuz. Okuma sirasında yazarın fikirlerine katıldiğınız ve katılmadı̆̆ınız yerleri belirleyiniz. 
"Düzenli yapılan spor, sağglıkl bir yaşam biçimini oluşturan dengeli beslenme benzeri diğer etkenlerle birleşince ileri yaşlarda oluşabilecek pek çok hastalı̆̆ önleyebilir. Böylece daha uzun ve daha mutlu bir yaşam sağlar." Kisaltılmıştır. (Bilim Çocuk, 2019: 178)

"Spor ve Bedenimiz" adlı metinde, öğretmenden öğrencilere sessiz okuma yaptırmaları beklenmektedir. Ancak okuma sırasında öğrencilerden, metinde yazarın fikrine katılıp katılmadıkları yerleri belirlemelerini istemek bizi eleştirel okuma yöntemine yönlendirmektedir. Eleştirel okuma, 8. sinıf okuma kazanımları içerisinde yer almaktayken; 5. sınıf metinlerinde yönlendirme yapılması müfredata uygun değildir.

- Metni sessiz okuyunuz. Metni okurken aşağıdaki soruların cevabını arayiniz.

"Hayatlarında bu kadar önemli olan bir şey için niçin bu kadar duyarsız davraniyorlardı? Savaşmayı bırakmalı mıydı? Yenilgiyi kabullenme düşüncesi bile kötüydü. Gözlerinin önüne fabrikadaki adamin gülüşü geliyordu. O mu kazanacaktı?" Kısaltılmıştır. (İbiş, 2019:68)

Yukarıdaki yönlendirme 5. sınıf ders kitabındaki "Bu Nehir Bizim" başlıklı hikâyeye aittir. Burada, öğrenciler sessiz okumaya yönlendirilmektedir. Ancak kitabın belirlediği sorulara cevap aramak, seçmeli esnek okumanın özellikleri arasındadır. Ancak seçmeli esnek okuma müfredatın hiçbir seviyesinde bulunmayan bir okuma yöntemi olmakla birlikte ortaokulun ilk seviyesindeki öğrenciler için de uygun değildir. Bu metin, içeriğiyle birlikte düşünüldüğünde tahmin ederek okumaya uygun bir metin olabilirdi. Metnin yönergesinde sessiz okuma yerine tahmin ederek ya da soru sorarak okuma tercih edilseydi Talim Terbiye Kurulunun müfredat planıyla doğru bir eşleşme yapılmış olacaktı.

- Metnin görsellerinden ve başlı̆̆ından hareketle metnin içeriğini tahmin ediniz. Okurken önemli gördüğ̈̈̈nüz yerleri işaretleyiniz.

"Mustafa Kemal, 23 Ağustos 1922 günü gizlice Konya'ya gitti. Oradan Akşehir'e vardl. Fevzi Çakmak ve İsmet İönü gibi ileri gelen komutanları çevresinde topladı. Birlikte bir taarruz planı hazırladılar"

Kısaltılmıştır. (Köklügiller, 2019:46)

"Dumlupınar Savaşı" isimli metnin yönergesinde tahmin ederek okuma istenmektedir. Tahmin ederek okuma 5. sinif müfredatında yer almasına rağmen metnin içeriğiyle uygun olmayan bir yöntemdir. Metinde genellikle tarihi bilgiler yer almakta, bu bilgiler bütünlük içerisinde aktarılmaktadır. "Okurken önemli gördüğünüz yerleri belirleyiniz.” ibaresi işaretleyerek okuma yönteminin özelliklerindendir. Ancak işaretleyerek

http://dergipark.gov.tr/aicusbed 6/2 Ekim / October 2020 
okuma 7. sınıf okuma kazanımlarında karşımıza çıkmaktadır. Bu metnin türü ve içeriğine göre tahmin ederek okuma; müfredata göre de işaretleyerek okuma uygun değildir. 5. sınıf müfredatında yer alan soru sorarak okuma yöntemi, metnin bilgi verici yönü düşünüldüğünde uygun bir yöntem olarak seçilebilir.

Müfredat programına göre 5. sınıflarda hızlı okuma yöntemi yer almasına rağmen Talim Terbiyenin onayladığı Türkçe kitabında bu okuma yönteminin adı geçmemekle birlikte bu yönteme herhangi bir yönlendirme de bulunmamaktadır.

\section{6. Sınıf Türkçe Kitabındaki Okuma Yöntem ve Metinler}

\section{Arasında Görülen Uyumsuzluklar}

6. sınıf okuma kazanımlarında yalnızca sesli, sessiz, tahmin ederek, not alarak, soru sorarak, hızlı okuma ve okuma tiyatrosu yöntemlerine yer verildiği halde ders kitabındaki okuma metinleri incelendiğinde yönergelerinde diğer okuma yöntemlerinin adı geçmeden uygulanması beklenmekte alt ya da üst kademe yöntemlerine yönlendirme yapılmaktadır.

- Aşağıdaki şiiri, şiirin bölümleri adedince gruplara ayrllarak söz korosu yöntemiyle okuyunuz.

"Bilir misin ki ben

Sen beni tutarsan uçarım

Bilir misin ki ben

Sen tutarsan gökyüzünden el sallarım” Kısaltılmıştır. (Neydim, 2019:74)

"Uçurtma" metninin, 6. sınıf müfredat okuma kazanımlarında yer almayan grup hâlinde ve söz korosu yöntemleri ile okunması beklenmektedir. Metnin şiir olması sebebiyle yönlendirmeler doğru olsa da bu yöntemlerin 6 . sınıf müfredatında yer almamaları çelişkiye sebep olmaktadır.

- Metni soru sorarak okuma yöntemi ile okuyunuz. Bunun için metni okumadan önce metnin başlığı ve görselleriyle ilgili zihninizde oluşan soruları tahtaya yazınız. Metni noktalama işaretlerine dikkat ederek sesli okuyunuz. Okuma sirasında, tahtaya yazdiğınız sorulardan cevaplandırılanların üzerini çiziniz.

“Işste kardeşler, 1921 yılı Ağustos'unda, Anadolu'da böyle yaman bir imece başladı. Anadolu halkı, Sakarya'da vuruşan ulusal halk ordusuna böyle arka verdi.” Kısaltılmıştır. (Kansu, 2019: 59)

"Anadolu İmecesi" isimli metnin yönlendirmesinde soru sorarak, tahmin ederek ve işaretleyerek okuma yöntemlerinin uygulanış şekillerine rastlanmaktadır. Adı geçen üç yöntem de metnin içeriğine uygundur ancak

http://dergipark.gov.tr/aicusbed 6/2 Ekim/ October 2020 
soru sorarak ve tahmin ederek okuma yöntemi 6. sınıf müfredatında yer alırken işaretleyerek okuma müfredata göre yalnızca 7. sınıfta uygulanması gereken bir yöntem olarak belirlenmiştir. Bu sebeple işaretleyerek okuma yöntemi müfredata göre bu metnin yönlendirmesinde yer alamaz.

\section{7. Sınıf Türkçe Kitabındaki Okuma Yöntem ve Metinler}

\section{Arasında Görülen Uyumsuzluklar}

Müfredat okuma kazanımlarında 7. sınıf kademesinde göz atarak, özetleyerek, not alarak, işaretleyerek ve tartışarak okuma yöntemleri yer almasına rağmen göz atarak, özetleyerek ve tartışarak okuma yöntemlerine hiç yer verilmediği aksine kazanımlarda adı geçmeyen sesli ve sessiz okuma yöntemlerine neredeyse metinlerin tamamında yer verildiği gözlemlenmektedir.

- Metni, noktalama işaretlerine, vurgu ve tonlamaya dikkat ederek ezbere okuyunuz.

"Güzel yurdum, dağlarını

Uzaktan göresim gelir.

Keskin esen yellerine

Kendimi veresim gelir" Kısaltılmıştır. (Kocatürk, 2019:117)

Ezberleyerek okuma yöntemi müfredata göre yalnızca 5. sinıfta uygulanması gereken bir yöntemken 7. sınıf ders kitabındaki "Yurt Türküsü" şiirinde "Metni, noktalama işaretlerine, vurgu ve tonlamaya dikkat ederek ezbere okuyunuz." yönlendirmesi dikkat çekmektedir.

- Metni önce türünün özelliklerine uygun biçimde ve bazı cümlelerin söyleyiş özelliklerine dikkat ederek sessiz okuyunuz. Daha sonra metni türünün özelliklerine göre canlandirarak sesli okuyunuz.

“Karısı —Karagöz'üm, çarşıya çıkmıyor musun?

Karagöz —Bugün çıkmayacağım. Hastayım.

Karısı —Olur mu, ayol! Bugün komşular gelecek.” Kısaltılmıştır. (Çakıcıoğlu, 2019: 179)

"Karagöz ile Hacivat" metninde sessiz ve sessiz okuma yapılması istenirken metnin türüne göre canlandırılması öğrenciyi okuma tiyatrosu yöntemine yönlendirmektedir. Okuma tiyatrosu bu metin için uygun bir yöntem olsa da 7. sınıf müfredatında bu yönteme yer verilmemesi ancak metinde bu yönteme yönlendirilmesi bir çelişkidir.

7. sınıf okuma kazanımlarında sesli ve sessiz okuma yönteminin isimleri geçmezken kitaptaki metinlerde 18 defa sesli, 11 defa sessiz okuma yöntemlerine başvurulması dikkat çekmektedir.

- Metni, önce sessiz, sonra sesli okuyunuz.

http://dergipark.gov.tr/aicusbed 6/2 Ekim / October 2020 
- Metni, noktalama işaretlerine dikkat ederek önce sessiz, sonra sesli olarak okuyunuz.

- Metni, önce sessiz, sonra sesli okuyunuz.

Yukarıda 7. sınıf Türkçe ders kitabındaki "Büyük Mimar Koca Sinan", "Küçük Yunus" ve "Anadolu Davulu" isimli metinlerin okuma yöntemlerine yönlendirmeler yer almaktadır. Dolayısıyla müfredatta yer alan okuma yöntemleri yerine müfredatta yer almayan okuma yöntemlerine başvurulmuştur.

\section{8. Sınıf Türkçe Kitabındaki Okuma Yöntem ve Metinler Arasında Görülen Uyumsuzluklar}

Türkçe Dersi Öğretim Programı 8. sınıf okuma kazanımlarında göz atarak, özetleyerek, not alarak, tartışarak ve eleştirerek okuma gibi yöntemlerden bahsedilmektedir. Ancak diğer kademelerde olduğu gibi bu kademede de tutarsizliklar vardır.

- Farklı yazı karakterleri ile yazılmış bölümlere dikkat ederek metni okuyunuz.

Bilişsel seviyesi bir kademe daha yükselen öğrenciler farklı okuma yöntemlerini kullanabilecekleri metinlerden uzak kalmaktadır. 5. sınıf metinlerinde olduğu gibi yukarıda yönlendirmesi yer alan "Simit ve Peynir'le Bilim İnsanı Öyküleri” isimli okuma metninin öncesindeki yönlendirmede bizi seçmeli-esnek okumaya götürmektedir. MEB müfredatında yer almayan bir yöntemin 5 . ve 8 . sinıflarda uygulanması müfredat ve ders kitapları arasındaki çelişkiyi göstermektedir.

- Görsellere ve metnin başlı̆̆ına bakarak metnin içeriğini tahmin ediniz. Metni noktalama işaretlerine dikkat ederek sesli okuyunuz.

"Çiftlikteki köylü kadınlar eve üşüştüler. Birtakım tekir kuşlar getiriyorlar, kesip kardeşimin boynuna sarıyorlardı. Babam, yatağının dibinden hiç ayrılmıyordu." Kısaltılmıştır. (Seyfettin, 2019: 22)

"Kaşağ1" tahmin ederek okuma yöntemi için içerik ve tür yönünden uygun bir metin olsa da bu yöntemin 8.sınıf müfredatında yer almaması metni müfredatla uyumsuz hale getirmektedir.

- Görsellere ve metnin başlı̆̆ına bakarak metnin içeriğini tahmin ediniz. Metni, önemli gördügüüüz yerleri defterinize not alarak okuyunuz.

"Internetten sürekli hastalı belirtilerini arama ve tedavi yöntemlerini araştırma hastalı̆̆ına ise "siberkondria" (saybırkondiria) adı verilmektedir." Kısaltılmıştır. (Kırık, 2019: 81)

http://dergipark.gov.tr/aicusbed 6/2 Ekim/ October 2020 
"Gündelik Hayatımızda E-Hastalıklar" metninde tahmin ederek ve not alarak okuma yöntemine başvurulmuştur. Ancak metin, içerik yönüyle tahmin ederek okumaya yönlendirilecek bir metin değildir. Daha çok bilimsel verilerin yer aldığı, akademik bir dille yazılan bu metin 8 . sınıf okuma yöntemlerinden olan ve 8 . sınıf Türkçe kitabında hiçbir metnin yönlendirmesinde yer almayan tartışarak okuma yöntemiyle de okunabilir.

- Metni, önemli gördügünüz yerlerin altını çizerek okuyunuz.

"Balıkhanede hiç tutmayan, fiyat bile verilmeyen on on beş dülger balı̆̆ kayı̆̆ı̆n küpeştesinde hâlâ canl, ince, zar gibi kanatlartyla titreşiyorlardl. Biraz sonra, işlerini bitirmiş olacaklar, hepsi orta parmaklarina birer dülger balığı takarak çekip gideceklerdi." Kısaltılmıştır. (Abasıyanık, 2019: 254)

8. sinıf ders kitabındaki "Haritada Bir Nokta" isimli metinde müfredat okuma kazanımlarında işaretleyerek okuma yöntemi yalnızca 7. sınıf okuma kazanımıyken 8. sınıf okuma metninde bu yöntemden bahsedilmiştir.

\section{Ortaokul ders kitaplarındaki okuma yöntem ve tekniklerinin}

\section{dağılımı}

Müfredatta kullanımda olan 5, 6, 7 ve 8. sınıf Türkçe kitaplarındaki tüm okuma metinleri incelendiğinde uygulanması beklenen okuma yöntem ve teknikleri aşă̆ıdaki gibidir.

Tablo 2. MEB Müfredatındaki Okuma Yöntem ve Tekniklerinin 5, 6, 7 ve 8. Sinıf Ders Kitaplarındaki Uygulanma Sayısı

\begin{tabular}{|l|c|l|l|l|l|l|l|l|}
\hline & \multicolumn{9}{|c|}{$\begin{array}{l}\text { Okuma Yöntem ve } \\
\text { Teknikleri }\end{array}$} & 5 & $\begin{array}{c}\text { Uygulama } \\
\text { Sayıs1 }\end{array}$ & 6 & $\begin{array}{c}\text { Uygulama } \\
\text { Sayıs }\end{array}$ & 7 & $\begin{array}{c}\text { Uygulama } \\
\text { Sayıs }\end{array}$ & 8 & $\begin{array}{c}\text { Uygulama } \\
\text { Sayı1 }\end{array}$ \\
\hline Sesli Okuma & $\mathrm{X}$ & 14 & $\mathrm{X}$ & 17 & $\mathrm{Y}$ & 18 & $\mathrm{Y}$ & 16 \\
\hline Sessiz Okuma & $\mathrm{X}$ & 6 & $\mathrm{X}$ & 2 & $\mathrm{Y}$ & 11 & & \\
\hline Tahmin Ederek Okuma & $\mathrm{X}$ & 6 & $\mathrm{X}$ & 3 & & & $\mathrm{Y}$ & 3 \\
\hline Not Alarak Okuma & $\mathrm{Y}$ & 3 & $\mathrm{Z}$ & 0 & $\mathrm{X}$ & 2 & $\mathrm{X}$ & 4 \\
\hline Grup Halinde Okuma & $\mathrm{X}$ & 1 & $\mathrm{Y}$ & 1 & & & & \\
\hline Soru Sorarak Okuma & $\mathrm{X}$ & 2 & $\mathrm{X}$ & 3 & & & & \\
\hline Söz Korosu & $\mathrm{X}$ & 1 & $\mathrm{Y}$ & 1 & & & & \\
\hline Ezberleyerek Okuma & $\mathrm{X}$ & 1 & & & $\mathrm{Y}$ & 1 & & \\
\hline Hızlı Okuma & $\mathrm{Z}$ & 0 & $\mathrm{X}$ & 1 & & & & \\
\hline Okuma Tiyatrosu & & & $\mathrm{X}$ & 1 & $\mathrm{Y}$ & 1 & & \\
\hline Göz Atarak Okuma & & & & & $\mathrm{Z}$ & 0 & $\mathrm{Z}$ & 0 \\
\hline Özetleyerek Okuma & & & & & $\mathrm{Z}$ & 0 & $\mathrm{Z}$ & 0 \\
\hline
\end{tabular}

http://dergipark.gov.tr/aicusbed 6/2 Ekim / October 2020 
446 |Dr. Öğr. Üyesi Metin ERKAL-Damla ÇAĞRITEKiN

\begin{tabular}{|l|l|l|l|l|l|l|l|l|}
\hline İşaretleyerek Okuma & Y & 4 & Y & 1 & X & 1 & Y & 1 \\
\hline Tartışarak Okuma & & & & & Z & 0 & Z & 0 \\
\hline Eleştirel Okuma & Y & 1 & & & & & X & 1 \\
\hline
\end{tabular}

X: Müfredatta yer alıp kitapta da uygulanan yöntemler

Y: 5,6,7 ve 8. sinıf kazanımlarında yer almayan ancak kitapta adı geçmeden uygulanması beklenen yöntemler

Z: Müfredat programında yer alan ancak kitapta hiç yer verilmemiş olan okuma yöntemleri

Tablodan da anlaşılacağı üzere MEB müfredatında yer alan kademelere göre okuma yöntem ve teknikleri ders kitaplarında uygun şekilde paylaştırılamamıştır.

\section{TARTIŞMA ve SONUÇ}

2019-2020 eğitim-öğretim yılında okutulmakta olan Türkçe ders kitaplarında okuma stratejilerinin (yöntem ve tekniklerinin) Türkçe ders kitaplarındaki metinlerle uyumunun incelenmesinin amaçlandığı bu çalışmada, müfredatın dışında okuma yöntem ve tekniklerin kullanıldığı tespit edilmiştir

Calp (2005: 97) araştırmalarda, sessiz okumada anlamanın daha iyi olduğunu ve bunun bireysel okuma eğitiminin temeli olduğunu, yüksek sesle okumanın ise gerileme ile sonuçlanabileceği ve yaşam boyu sürecek okuma yanlışlarına yol açabileceğini gösterdiğini bu yüzden sesli okuma oranının, yüksek sınıflara geçtikçe azaltılması gerektiğini ifade etmiştir. Ancak yürürlükteki kitaplardaki tüm kademelerde çoğu metin sesli okuma yöntemiyle okunmakta diğer yöntem ve tekniklere çok az yer verilmektedir. $\mathrm{Bu}$ durum öğrencilerin okuduğunu anlamalarını güçleştirmektedir.

Türkçe kitaplarındaki metinlerde öğrencinin estetik zevkinin amacı doğrultusunda kazanılıp metnin anlamlandırabilmesi için metin türü ile bağdaştırarak bir okuma yapması gerekmektedir. Bu okuma türü yeni müfredatın önerdiği kitaplarda doğrudan söylenmekte ya da dolaylı olarak sezdirilmektedir. Günümüz öğrencilerinin çoğu, metinleri sesli olarak dile getirmekte öğretmenlerin yardımı olmadan okuma yöntem ve tekniklerini kullanamamaktadırlar. Bunun yanında kitap okuma alışkanlığını kazanabilmeleri için sessiz okumaya da büyük önem göstermektedirler. Ancak üst bilişsel düşünme becerilerini kazanabilmek için farklı okuma yöntemlerini gerçekleştirebilmek gerekir.

Birey, kalıplaşmış yöntemlerle ancak kalıplaşmış bilgileri öğrenip kendi hayatında uygulayabilmektedir. Empatik okuma, eleştirel okuma, tartışarak okuma, soru sorarak okuma günümüzde kazanılması gereken

http://dergipark.gov.tr/aicusbed 6/2 Ekim/ October 2020 
önemli okuma becerileridir. Ancak Tablo 2'de görüldügü üzere sesli ve sessiz okuma tüm kademelerde en büyük payı almıştır.

5. sınıf seviyesinde birçok okuma yöntemine başvurulsa da okuduğunu anlamlandırmada en önemli faktör olan ve konunun ana hatlarıyla kavranmasını sağlayan özet, hiçbir metnin okuma yönteminde yoktur. Öğrenciler özet yaparak, okuma becerilerinin yanında konuşma ve yazma becerilerini de geliştirmiş olurlar ancak 5. sınıftan 8. sınıfa kadar hiçbir kademede bu becerinin sağlanmasına firsat yaratacak metin yer almamaktadır. Oysa müfredatta 7. ve 8. sinıf okuma yöntemleri arasında bulunan özetleyerek okuma daha alt kademelerden itibaren kazandırılması gereken bir beceridir.

Yazma becerisini de geliştiren not alarak okuma yöntemi, müfredatta 6. sınıfın okuma yöntem ve teknikleri arasında yer alırken; 5,7 ve 8 . sınıf metinlerinde uygulanmış olup 6. sınıf metinlerinin hiçbirinde yer almamaktadır. Bu durum, öğrencileri okuma sürecinde pasif kılmakta, onların önemli bilgi, düşünce ve olayları hatırlayamamalarına sebep olmaktadır. $\mathrm{Bu}$ nedenle okuma becerilerinin yanında yazma ve konuşma becerilerini de geliştiren yöntem ve teknikler müfredatın her aşamasında yer alıp ders kitaplarında yer edinmelidir.

Okuma becerisinin yanında konuşma becerisini de artıran tartışarak okuma yöntemi öğrencilere demokratik bir tutum kazandırarak öğrencilerin demokratik konuşmanın sürecini ve yapısını öğrenmelerine yardımcı olur. (Brookfield ve Preskill, 1999:38) Öğrencilerin diğer öğrencilerin fikirlerine saygı duymasını, hoşgörü kazanmasını sağlayan bu yöntem müfredatta 7 . ve 8. sınıf okuma yöntemleri arasında yer almaktadır. Ancak tüm kademelerin Türkçe ders kitabı incelendiğinde bu yönteme yer verilmediği gözlenmiştir. Tartışma, öğretim tekniği olarak metinlerin etkinliklerinde yer almıştır.

Günümüzde, yayın, tür ve sayılarının çokluğu ve her gün bunlara yenisinin de eklendiği düşünüldügünde göz atarak okumanın önemi ortaya çıkmaktadır. Çünkü her metin bizi ilgilendirmez ve bu yöntem bize zaman kazandırır. Böylesine önemli bir okuma yönteminin müfredata göre 7 . ve 8 . sınıflarda öğrenciye kazandırılması gerekmektedir. Ancak ders kitaplarında değil adı yönlendirmesi bile bulunmayan göz atarak okuma yöntemiyle ilgili bu durum bir çelişkidir.

7 ve 8. sınıf seviyesi öğrencilerde bilişsel olarak algılama kapasitesi artmaktadır. Buna rağmen dil becerilerini geliştirme dersinde, okuma becerilerinin yanında yazma ya da konuşma becerisini geliştirecek yöntemlere yer verilmemesi olumsuz bir izlenim oluşturmaktadır. Bununla birlikte okunan bir metnin yorumlanması ve değerlendirilmesi, okumanın ve Türkçe

http://dergipark.gov.tr/aicusbed 6/2 Ekim / October 2020 
müfredatı okuma kazanımlarının her zaman en önemli basamaklarından biri olmuştur.

Güncel Türkçe müfredatında eleştirerek okuma yöntemi 8. sınıf öğrencilerinin kazanımlarında yer almaktadır. Çünkü 15 yaşından küçük bir öğrencinin eleştiri yapma yeteneği tam olarak gelişmemiştir. Liseye geçiş aşamasında öğrenciler olaylara farklı açılardan bakmaya başlarlar. Piaget ve Inhelder'e göre (Ahioğlu ve Lindberg, 2011: 6) ergen bir problemle karşılaştı̆̆ında aynı anda pek çok faktörü içeren bileşimsel bir mantık kullanmaktadır. Eleştirel okuma becerisi üst düzey zihinsel beceriler (analiz, sentez, değerlendirme) gerektirdiğinden ilkokuldan sonra aşama aşama ögrenciye kazandırılmalıdır. Her ne kadar öğretmenler 5, 6 ve 7. sınıf aşamalarında da öğrencilerin eleştirel yorum yapmalarına önem gösterse de öğrenciler 8. sınıfa geldiklerinde kelime hazinelerinin ve deneyimlerinin de artmasıyla daha elle tutulur yorumlar yapmaya başlarlar. Zira Türkçe dersi ifade ve beceri dersidir. Buna rağmen eleştirel okuma, 8. sinıf Türkçe ders kitabında yalnızca tek metinde okuma yöntemi olarak kullanılmıştır. Günümüz koşulları göz önünde bulundurulduğunda doğru bilgiye ulaşabilmek için bu becerinin öğrencilere kazandırılması ve bu yöntemin daha çok metinde uygulanabilmesi gerekmektedir.

\section{ÖNERILLER}

1. Derslerde okuma becerisinin yanında diğer dil becerilerini de geliştiren okuma yöntem ve teknikleri kullanılabilir.

2. Serbest okuma metinleri, müfredatta yer alan; ancak hiçbir metinde kullanılmayan, okuma yöntemleriyle okunabilir.

3. Öğrencilere gelişim sevilerine göre müfredatta yer almayan diğer okuma yöntem ve teknikleriyle ilgili okumalar yaptırılabilir.

4. Çocuğu hayata hazırlamak için ifade ve beceri durumlarına göre muhakeme/yorum gücünü artırabilecek okuma etkinliklerinin sayısı artırilabilir.

5. Ders kitapları hazırlanırken metin/strateji birlikteliğine daha fazla yer verilebilir.

\section{Kaynakça}

Abasıyanık, S.F. (2019). "Haritada Bir Nokta”. Hilal Eselioğlu, Sıdıka Sert ve Ayşe Yücel. Ortaokul ve İmam Hatip Ortaokulu Türkçe 8. Sınıf Ders Kitabı içinde (s. 252-255). Ankara: MEB Yayınları.

Ahioğlu, E. N. ve Lindberg. (2011). "Piaget ve Ergenlikte Bilişsel Gelişim". Kastamonu Eğitim Dergisi. 19 (1), s. 1-10. 
Albayrak, M. ve Erkal, M. (2003). "Başarıya Giden Yolda İfade ve Beceri Derslerinin (Türkçe-Matematik) Birlikteliği”. Milli Eğitim Dergisi. 158.

Arıcı, A. (2009). "Okuma Eğitimi”. Ankara: Pegem Akademi.

Arslan, A. ve Engin, A.O. (2019). "5. Sınıf Türkçe Ders Kitabının Öğretmen Görüşlerine Göre Değerlendirilmesi”. Uluslararası Türk Eğitim Bilimleri Dergisi, 7 (13), s. 67-94.

Bilim Çocuk. (2019). "Spor ve Bedenimiz". Şule Çapraz Baran ve Elif Diren. Ortaokul ve İmam Hatip Ortaokulu Türkçe 5. Sınıf Ders Kitabı içinde (s. 178). Ankara: Anıttepe Yayıncılık.

Brookfield, S. D. ve Preskill, S. (1999). "Discussion as a way of teaching: tools and techniques for democratic classroom". San Francisco: Jossey Bass.

Calp, M. (2005). “Özel Öğretim Alanı Olarak Türkçe Öğretimi”. (2. Baskı). Ankara: Eğitim Kitabevi.

Çakıcıŏlu, E. (2019). "Karagöz ile Hacivat”. Hilal Erkal ve Mehmet Erkal. Ortaokul ve İmam Hatip Ortaokulu Türkçe Ders Kitabı 7. Sınıf içinde (s. 179-183). Ankara: Özgün Yayıncılık.

Çalışkan, G. (2016). "Türkçe Dersi Öğretim Programı ve Türkçe Ders Kitapları: 5. Sınıf Türkçe Ders Kitabına Yönelik Bir İnceleme”. Ana Dili Eğitimi Dergisi, 4(2), 200-214.

Göğüş, B. (1978). "Orta Dereceli Okullarımızda Türkçe ve Yazın Eğitimi”. Ankara: Gül Yayınevi.

Gülersoy, A.E. (2013). "İdeal Ders Kitabı Arayışında Sosyal Bilgiler Ders Kitaplarının Bazı Özellikler Açısından İncelenmesi”. International Journal of New Trends in Arts, Sports \& Science Education - 2013, volume 2, issue 1 Copyright (C) International Journal of New Trends in Arts, Sports \& Science Education 8

Gündüz, O. ve Şimşek, T. (2013). “Anlama Teknikleri 1. Uygulamalı Okuma Eğitimi El Kitabı”. Ankara: Grafiker Yayınları.

İbiş, N. (2019). "Bu Nehir Bizim”. Şule Çapraz Baran ve Elif Diren. Ortaokul ve İmam Hatip Ortaokulu Türkçe 5. Sınıf Ders Kitabı içinde (s. 6872). Ankara: Anittepe Yayınc1lik.

Kansu, C.A. (2019). “Anadolu İmecesi”. Tuncay Demirel. Ortaokul ve İmam Hatip Ortaokulu 6. Sınıf Ders Kitabı içinde (s. 57-59). Ankara: Ekoyay Yayıncilik.

Karasar, N. (2004). "Bilimsel Araştırma Yöntemi”. Ankara: Nobel Yayın Dağıtım. 
Karatay, H. (2014). “Okuma Eğitimi Kuram ve Uygulama”. 2. Baskı. Ankara: Pegem Yayınevi.

Kırık, A.M. (2019). “Gündelik Hayatımızda E-Hastalıklar”. Hilal Eselioğlu, Sidıka Sert ve Ayşe Yücel. Ortaokul ve İmam Hatip Ortaokulu Türkçe 8. Sınıf Ders Kitabı içinde (s. 80-81). Ankara: MEB Yayınları.

Kocatürk, V.M. (2019). "Yurt Türküsü". Hilal Erkal ve Mehmet Erkal. Ortaokul ve İmam Hatip Ortaokulu Türkçe 7. Sınıf Ders Kitabı içinde (s. 117). Ankara: Özgün Yayıncılık.

Köklügiller, A. (2019). "Dumlupınar Savaşı". Şule Çapraz Baran ve Elif Diren. Ortaokul ve İmam Hatip Ortaokulu Türkçe 5. Sınıf Ders Kitabı içinde (s. 46-47). Ankara: Anıttepe Yayıncılık.

Maden, S. (2018). "Okuma Eğitimi". Oğuzhan Sevim ve Yusuf Söylemez (Ed.) Okuma Yöntem ve Teknikleri içinde (s. 233-256). Ankara: Nobel Basımevi.

Millî Eğitim Bakanlığı. (2019). "Türkçe Dersi Öğretim Programı, (İlkokul ve Ortaokul 1, 2, 3, 4, 5, 6, 7 ve 8. Siniflar)", Ankara.

Mutlu, H., Sügümlü, Ü. ve Çinpolat, E. (2019). "Türkçe Dersi Öğretim Programı (2018) Temelinde Hazırlanan Ortaokul Türkçe Ders Kitaplarının Öğretmen Görüşleriyle Değerlendirilmesi”. Millî Eğitim Dergisi, Cilt: 48 Say1: 224, (101-121)

Neydim, N. (2019). "Uçurtma". Tuncay Demirel. Ortaokul ve İmam Hatip Ortaokulu 6. Sınıf Ders Kitabı içinde (s. 74-75). Ankara: Ekoyay Yayınc1lik.

Önder, M. (2019). “Anadolu'da Konukseverlik Gelenekseldir”. Şule Çapraz Baran ve Elif Diren. Ortaokul ve İmam Hatip Ortaokulu Türkçe 5. Sınıf Ders Kitabı içinde (s. 23-24). Ankara: Anıttepe Yayıncılık.

Seyfettin, Ö. (2019). "Kaşağı”. Hilal Eselioğlu, Sıdıka Sert ve Ayşe Yücel. Ortaokul Ve İmam Hatip Ortaokulu Türkçe 8. Sınıf Ders Kitabı içinde (s. 20-22). Ankara: MEB Yayınları.

Şahin, T. (1998). "Amerika'da ilkokul 5. sinıflarda okutulan ana dili ders kitabının değerlendirilmesi”, Dünyada ve Türkiye'de anadili eğitimi. Sempozyum Bildirileri, Ankara Üni. Ankara: Tömer Yayınları.

Temizkan, M. (2009). "Metin Türlerine Göre Okuma Eğitimi”. (1. Baskı) Ankara: Nobel Basımevi. 